\title{
Reserach Aвтіск: : Direct sown paddy with seed drill - Adoption status of Krishna district farmers in Andhra Pradesh
}

\section{P. Srilatha and Ch. Srilatha Vani}

Article Chronicle: Received :

15.02.2020;

Revised:

03.10.2020;

Accepted :

$22 . .10 .2020$

\section{KeY Words :}

Direct sown paddy, Seed drill, Adoption of the technologys
SSUMMARY : In Krishna district of Andhra Pradesh, majority of the farmers were cultivating rice in a traditional method i.e., transplanting of rice under tanks and canals as source of irrigation. Due to late receipt of the water in the canal tail end regions, sowing of the second crop is becoming late which leads to yield loss. In future, water and labour availability may worsen which may lead to increased competition for these aspects. Therefore, Krishi VIgyan Kendra, Ghantasala endeavored to create awareness on direct sown paddy with seed drill and has been promoting this method since 5-6 years. Andhra Pradesh State was selected purposively for this study and the survey was conducted in Krishna district. 120 rice growers were considered for the present study. The data was collected from the farmers through personal interview with the help of pre-tested scheules and questionnaire. The results showed that 51.66 per cent of the respondents belonged to high adoption category, followed by 29.16 per cent belonged to medium adoption and 19.16 per cent of the respondent belonged to low adoption categories which means partial adoption of direct sown paddy with seed drill respectively. As per recommendations of the Scientists of Krishi Vigyan Kendra, Ghantasala, more than half of the respondents had high level of adoption. It can be concluded that direct sown paddy is getting more popular in Krishna district and farmers are more motivated towards adoption of the technology. More than half of the farmers are adopting the recommended package of practices. So, farmers should be motivated to adopt 100 per cent technology which created a positive impact on farming community.

How to cite this article :Srilatha, P. and Srilatha Vani, Ch. (2020). Direct sown paddy with seed drill - Adoption status of Krishna district farmers in Andhra Pradesh. Agric. Update, 15(4): 363-367; DOI : 10.15740/HAS/AU/ 15.4/363-367. Copyright@ 2020: Hind Agri-Horticultural Society.
Author for correspondence :

\section{P. Srilatha}

Krishi Vigyan Kendra, Ghantasala, Krishna

(A.P.) India

Email : srilathajeyabal@

gmail.com

See end of the article for

authors' affiliations 